\title{
Web Quest and EFL Critical Reading and Writing
}

\author{
Mervat Abd Elfatah Ali Said Ahmed \\ Qassim University, Qassim, Saudi Arabia
}

\begin{abstract}
This study aimed at investigating the effect of using a Web Quest program on developing some EFL critical reading and writing skills of the first year experimental secondary school students. The participants of the study were 60 students from one of the Experimental Secondary Schools in Egypt. Instruments of the study were EFL critical reading and writing tests. Students in both the experimental and the control groups were pre-tested using the critical reading test and the writing test. Then, students of the experimental group were using Web Quest. Finally, students in both groups were post-tested using the same instruments. The study showed that there was statistically significant difference between the mean scores of the pre and the post critical reading test and writing test of the experimental group in favor of the post tests. This difference can be attributed to using Web Quest.
\end{abstract}

Keywords: Web Quest, EFL critical reading and writing

Critical reading is one of the major language skills which experimental secondary stage students have to practice. It is being more than the ability to understand the explicit meaning of a passage. It involves application, analysis and evaluation. It is the process, in which students participate in an inner dialogue with the reading text, identify the audience, make inferences, and guess the meaning of words in context. In addition, students are able to show cause and effect, find the evidence the text employs, recognize the bias and tone of the writer, and determine the author's point of view and his intended meaning (Phillips \& Sotiriou, 1992).

Although critical reading is a very important skill, the studies of Ebada (2002) and Kamal (2011) directed the attention in their studies to the lack of teaching EFL critical reading at the Egyptian schools due to emphasizing surface-level information processing techniques such as memorization and rehearsal and losing the chance for performing reading tasks which involve higher order thinking skill such as hypothesizing, synthesizing, comparing/contrasting, applying, and evaluating.

Hyland (2002) indicated that critical reading is a source for writing.

Reading source texts provides writers with content that any competent reader would infer from the source text. As there is a lack of teaching critical reading at the Egyptian schools, EFL writing is a neglected skill and secondary stage students face many difficulties in grammar, spelling, word order, vocabulary choice, the organization and development of their writing (Helal, 2003; Abdel-Razek, 2006). To overcome these problems in critical reading and writing, Web Quest is used as one of the most-update computer applications.

Web Quest is "an inquiry-oriented activity in which some or all the information that learners interact with comes from sources on the Internet” (Dodge, 1995).

It is operationally defined as a scaffold and inquiry-based learning in which the teacher supplies students

Mervat Abd Elfatah Ali Said Ahmed, Ph.D., Assistant Professor, Oklt Al Sqoor College of Science and Arts, Qassim University.

Correspondence concerning this article should be addressed to Mervat Abd Elfatah Ali Said Ahmed. 
with tasks and authentic web resources to perform the tasks, take roles in small groups, read the web resources critically to carry out these roles and tasks and write summaries.

Web Quest is used as one of the most-update computer applications for the following reasons: It develops critical thinking; it increases students' motivation to learn; it increases opportunities for collaboration to complete the given task; it provides authentic situations and opportunities for role-play; it is a student-centered and project-based approach to teaching and learning and it allows students to receive input in the form of reading information and generate output in the form of essays and summaries (Dodge, 1995).

Many studies integrate Web Quest to develop EFL reading and writing as follows:

Tsai (2005) conducted a study to determine the effects of utilizing the Web Quest as a CAI on the traditional EFL reading instruction in a target university in Taiwan. An EFL reading comprehension test and an attitudinal survey towards the Web Quest learning were used. The results indicated that the students who use Web Quest produced significant difference in students' vocabulary acquisition and story reading performance. The results of the survey indicated an overall positive attitude towards Web Quest learning.

In addition, Kocoglua (2010) designed a university reading/writing course to integrate Web Quest tasks into EFL reading/writing instruction. The purpose of the study was to compare the effects of Web Quest on Turkish EFL university students' reading and writing performance on a Fresh man class. The results indicated that the experimental group scored higher on reading than did the control group. On the other hand, both groups scored equally on writing process.

In the same way, Noordin, Samed, and Razali (2008, pp. 36, 66, 80) surveyed a group of Malaysian student teachers in a TESL; they participated in three computer lab sessions that introduced them to Web Quest and involved them in a sample activity. A questionnaire was administered to elicit these student teachers' perceptions on the practicality of Web Quest in EFL classrooms. The results showed that Web Quests are beneficial to English learning. This study is different from the previous studies that it used Web Quest to develop some EFL critical reading and writing.

A typical Web Quest has the following components:

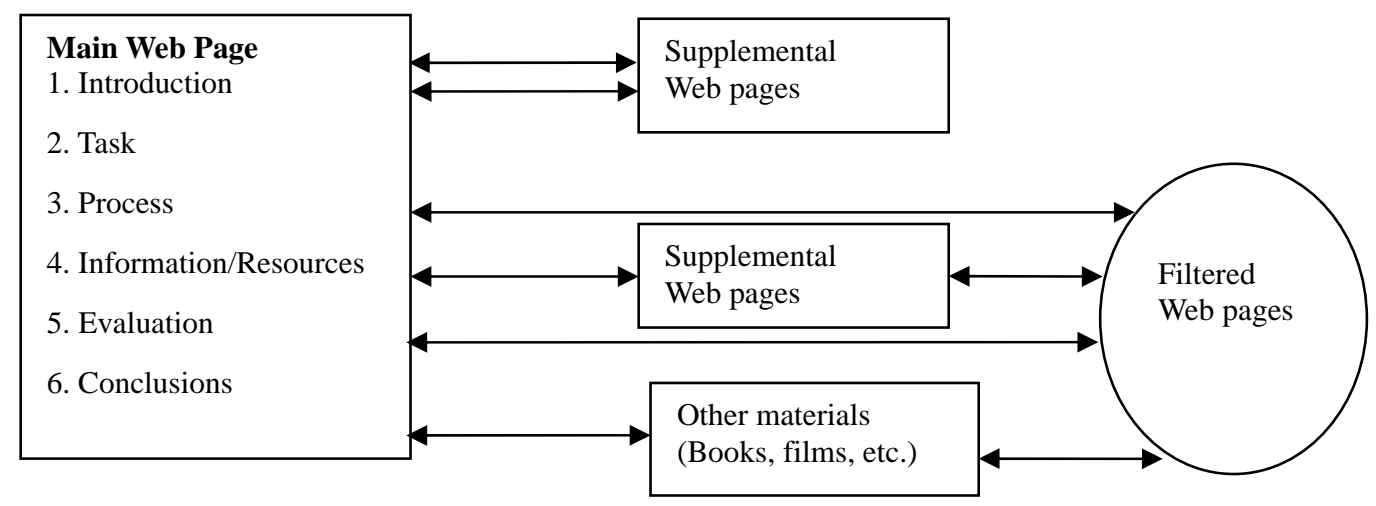

Figure 1. A typical Web Quest.

Purpose of the study:

This study aimed at investigating the effect of Web Quest on critical reading and writing in English as a foreign language.

Questions of the study:

This study tried to answer the following questions: 
(1) What is the effect of Web Quest on critical reading in English as a foreign language?

(2) What is the effect of Web Quest on writing skill in English as a foreign language?

Participants of the study:

Participants of the study were 60 students at first year secondary at Fakus Experimental language school. They were divided into two groups: experimental group $(n=30)$ and control group $(n=30)$.

Instruments of the study:

This study used the following instruments:

(a) An EFL critical reading test.

(b) EFL writing test and they were indicated as follows.

\section{EFL Critical Reading Test}

The critical reading skills test was used to measure the students' ability to use the critical reading skills which they need at this stage of learning. The test consists of two comprehension reading passages with thirty critical reading questions which measure students' level in critical reading. These items have been submitted to a jury to judge their suitability to the experimental secondary school students' level. The items of the test reflect the critical reading skills dealt with in the study.

\section{Validity of the Critical Reading Test}

\section{Face Validity}

The critical reading test was administered to a jury $(n=9)$ of professors of curricula and teaching methods who indicated that the test is valid and no modifications were suggested.

\section{Content Validity}

According to Key (1997) "Content validity refers to the degree to which the test items represent the domain or universe of the trait or property being measured", so the critical reading test is a performance test which measures students' ability to practice and master critical reading skill. Then, it can be said that the content of the test is valid.

\section{EFL Writing Test}

The writing test was used as a pre-and post-test to identify how far first year secondary school students master EFL writing skills and determine whether EFL writing skills are developed as a result of teaching writing using Web Quest.

\section{Description of the Writing Test}

The test consisted of two essay writing questions. In the first essay, students are asked to choose one of the topics and write an essay about it. The second question asks the students to write a persuasion essay.

\section{Face Validity}

The EFL writing test was presented to a jury $(n=9)$ of professors of curricula and teaching methods who indicated that the test was valid. There were no modifications.

\section{Content Validity}

According to Key (1997), "Content validity refers to the degree to which the test items represent the domain or universe of the trait or property being measured”. Since the test measures the students' ability to write and the jury indicated that, the writing test measures this ability so it can be said that the test is valid.

\section{Materials of the Study}


The materials of the study were two rubrics which were designed by the researcher: one to correct the EFL critical reading test and the other to correct the EFL writing test.

\section{Study Design}

Web Quest was used as an experimental variable in this study and EFL critical reading and writing were used as control variables in this study. This study followed the pre-test/post-test experimental-control group design. This design can be illustrated in Figure 2.

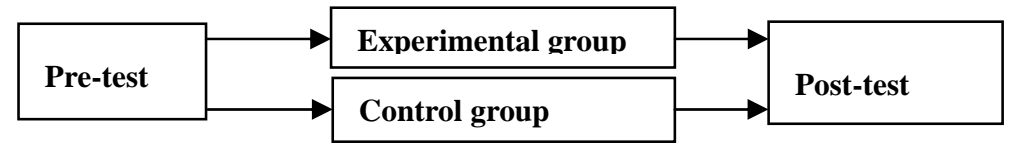

Figure 2. The experimental design used in the present study.

The integration of Web Quest with critical reading and writing:

- Constructing an EFL critical reading test, a writing test and rubrics to assess them and submitting them to a jury to determine their validity.

- Modifying the tests and the rubrics according to the jury's suggestions in their final form.

- Selecting a random sample of the experimental first year secondary school students in one of the experimental secondary school, and randomly dividing them into two groups (control and experimental).

- The sample is 35 first year experimental secondary stage students. These students study an advanced course "Move Ahead Plus".

- Administering the critical reading test and the EFL writing test to the experimental and control group to identify the students' real standard concerning the identified critical reading and writing skills.

- Teaching the experimental group EFL critical reading and process writing using Web Quest program and the control group in the traditional method.

- Applying the EFL critical reading test and the writing test to the two groups after teaching (post tests). The way of teaching the experimental group went as follows:

- The teacher uses Web Quest as a tool to develop these students' critical reading and writing.

- Web Quest is integrated with six units of the course "Move Ahead Plus".

- The steps of teaching are integrated with Web Quest parts and critical reading (pre-reading, reading and post reading) and writing (pre-writing, writing and post writing).

Table 1

The Integration of Web Quest With EFL Critical Reading and Writing

\begin{tabular}{|l|l|}
\hline Parts of the Web Quest & Steps of teaching \\
\hline $\begin{array}{l}\text { Introduction } \\
\text { (to gain students' attention and introduce the topic) }\end{array}$ & Pre-reading phase \\
\hline $\begin{array}{l}\text { Task } \\
\text { (doable and interesting) }\end{array}$ & \\
\hline $\begin{array}{l}\text { Process } \\
\text { (to provide step by step instructions, resources and guidance for students in } \\
\text { order to complete the task) }\end{array}$ & Reading phase \\
\cline { 2 - 2 } & Post-reading phase/ Pre-writing phase (planning) \\
\cline { 2 - 2 } $\begin{array}{l}\text { Evaluation } \\
\text { (to provide rubrics on how the task will be evaluated) }\end{array}$ & Post-writing phase (revising and editing) \\
\hline $\begin{array}{l}\text { Conclusion } \\
\text { (to bring closure to the activity or extend the gained knowledge to other domains) }\end{array}$ & \\
\hline
\end{tabular}

- Web Quest is integrated with the first and the third part of Move Ahead Plus. 
- The first part has two comprehension reading passages with questions which are modified according to critical reading skills.

- The third part consists of writing summaries.

- The Web Quest is carried out using Front Page Program.

- The title of the Web Quest is specified according to the title of the unit of Move Ahead Plus.

A practical example about integrating Web Quest

An-Introduction

- The teacher asks students:

Why did Thomas Edison invent the light bulb?

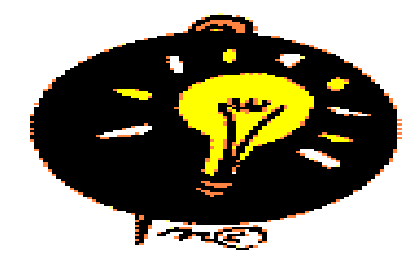

Why did Graham Bell invent the telephone?

- The teacher tells the students about the greatness of the Ancient Egyptians and the Chinese.

- The teacher asks the students to explore some of their inventions now:

* Firstly, students make a list of ten of the most important inventions of all Times.

* Secondly, students in groups make comparison between three of these:

First car/New Prius electric car

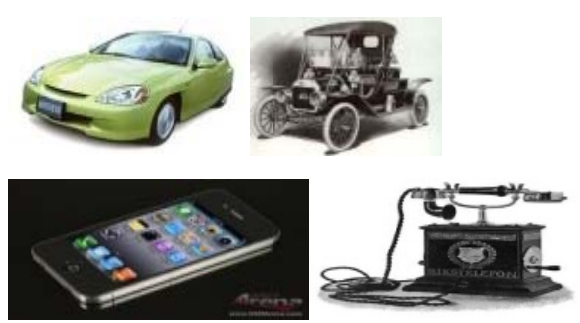

First telephone/Iphone 4

First light bulb/Energy Saving Light bulb
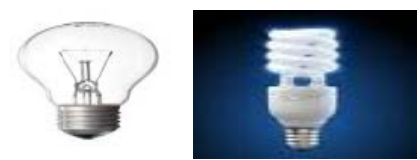

* Thirdly, students in groups answer the pre-reading questions (pre-reading stage)

Ex: Who were the first people to use papyrus?

Who were the first people to use paper?

* Fourthly, students critically read the passage about papyrus and inventing paper to answer the pre-reading questions.

B-The Task:

-Students critically read the passage about papyrus and inventing paper to answer the pre and post reading questions.

-Students work in groups to read the Internet resources about papyrus and inventing paper to write a 
summary about papyrus and inventing paper.

-The teacher asks the students to describe the dynasty of inventing paper, its usefulness and write a summary at the end.

C-The Process:

(1) Students critically read the passage about papyrus and inventing Paper (peading phase) to answer the post reading questions (post reading phase). Ex: Questions about the tone of the passage, its purpose, its conclusion, making generalization, making assumptions, etc.

(2) Students are divided into groups of three to write a summary about papyrus and inventing paper by making use of the Internet links in the resources part:

* Students read about the invention and take notes (pre-writing stage).

* The teacher asks the students to answer the questions about papyrus and inventing paper such as:

What need do they satisfy?

Who invented them?

What year were they invented? Etc.

(3) After taking notes, the teacher tells the students that the summary should include papyrus and the invention of paper, their development, the steps of making them, their influence on society, the industries related to them, their movement to Europe and their influence on our daily life today (writing stage).

(4) Then, the teacher discusses with the students the characteristics of a good summary, its steps and gives an example about it.

\section{D-Evaluation: Post writing stage:}

After students write their summaries, they give them to their classmates for peer-editing (Post-writing stage). Then, they assess their summaries using the summary rubric provided at the end of the Web Quest. Finally, the teacher assesses the summaries using the summary rubric provided at the end of the Web Quest.

\section{E-The conclusion:}

The teacher sums up those students have done a good job as they can follow how papyrus and paper were developed from Ancient Egypt to China and they can benefit from their critical reading of the passage and web in writing their summaries.

\section{Results of the Study}

\section{This Study Showed the Following Results}

Table 2

Results of the T-test of the Post-test of the Experimental and the Control Groups in the Critical Reading Test

\begin{tabular}{lllllll}
\hline Group & $\mathrm{N}$ & Mean & S.D. & $t$-value & df. & Sig. \\
\hline Experimental & 30 & 104.63 & 2.25 & 62.31 & 60 & Sig \\
Control & 30 & 54.53 & 3.79 & & & \\
\hline
\end{tabular}

It is obvious from Table 2 that there is statistically significant difference at 0.05 (one-tailed) between the mean scores of the experimental group (X1 = 104.63) and the control group (X2 = 54.53) in the post-test of the critical reading test in favor of the experimental group as indicated by $t$-value (62.31). This difference may be attributed to the effect of Web Quest. 


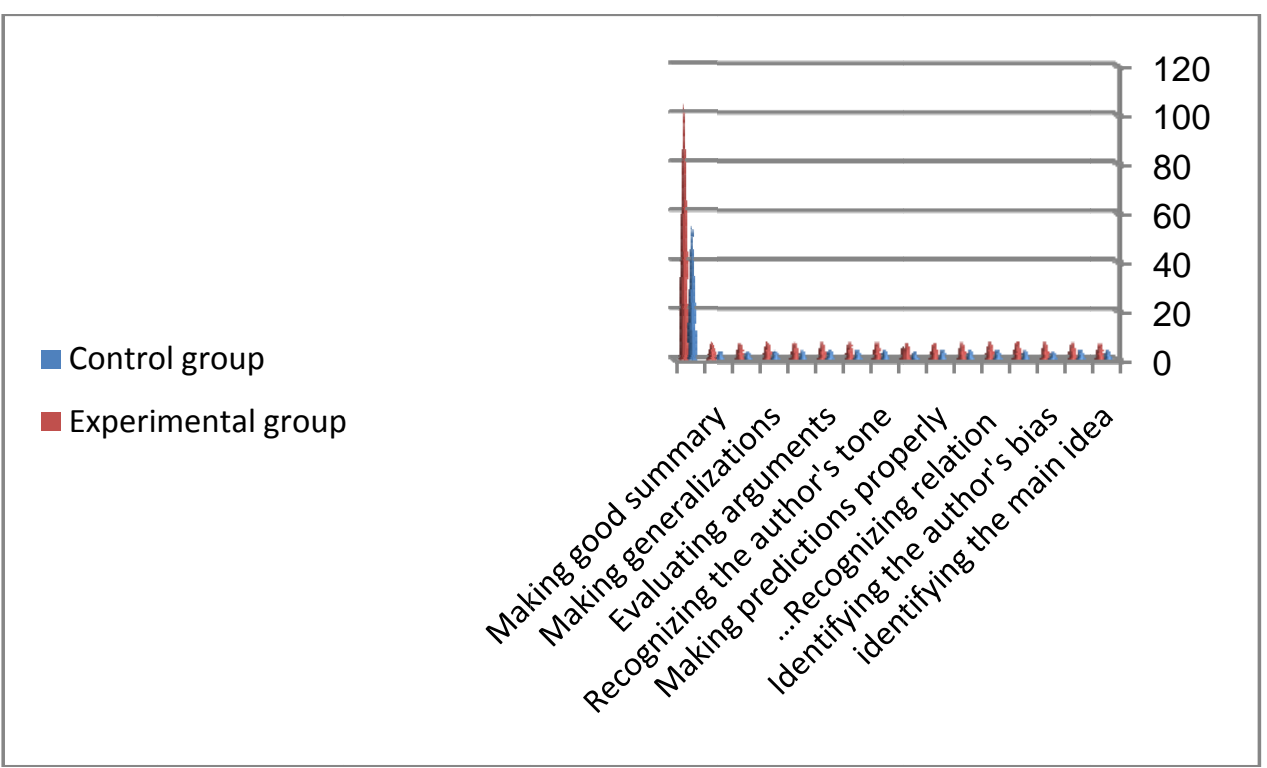

Figure 3. The mean scores of the experimental and control group in the post-test of critical reading and its skills.

Table 3

Results of the T-test of the Post-test of the Experimental and the Control Group in the EFL Writing Test

\begin{tabular}{lllllll}
\hline Group & $\mathrm{N}$ & Mean & S.D. & $t$-value & df. & Sig. \\
\hline Experimental & 30 & 50.90 & 1.52 & 60.09 & 60 & Sig \\
Control & 30 & 20.53 & 2.32 & & & \\
\hline
\end{tabular}

Table 3 shows that there is statistically significant difference at 0.05 between the mean scores of the experimental group $(\mathrm{X} 1=50.90)$ and the control group $(\mathrm{X} 2=20.53)$ in the post-test of writing in favor of the experimental group as indicated by $t$-value (60.9). This difference may be attributed to the effect of Web Quest.

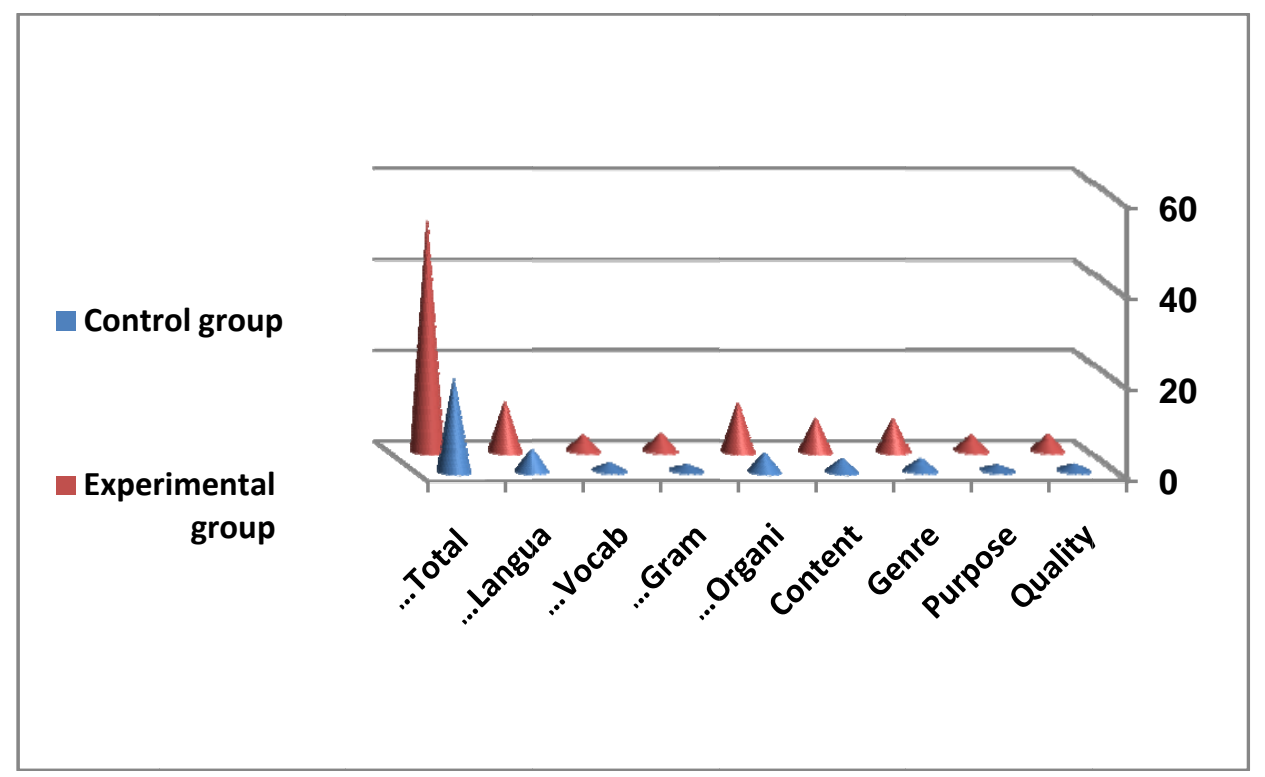

Figure 4. The mean scores of the experimental and control group in the post-test of writing and its sub-skills. 


\section{Discussion}

The discussion of the findings included:

(1) The effect of Web Quest on students' critical reading.

(2) The effect of Web Quest on students’ process writing.

\section{The Effect of Web Quest on Students' Critical Reading}

The effect of Web Quest on students' critical reading was investigated and determined in comparison with that of traditional critical reading instruction. As shown by the results of the study, students in the experimental group improved their critical reading significantly (see Table 2).

To the knowledge of the researcher, there is no study which dealt with the effect of Web Quest on critical reading but some studies have dealt with the effect of Web Quest on reading skill such as Puthikanon (2009), Kocogula (2010), and Chen (2011) who proved that Web Quest has a positive effect on EFL students’ reading skill.

Speculation can be made to explain why the Web Quest was more effective than the traditional critical reading instruction. The fundamental distinction between these two instruction methods was found in the effective features of the Web Quest as the tasks are authentic that motivate students to be actively engaged in the instructional process, and the abundant scaffolding was found to be useful for the performance of critical reading.

The reading input in the Web Quest was the reading comprehension passages in the book of Move Ahead Plus for the first year experimental secondary stage students and the web materials presented on given websites. Students received the reading input by surfing these web materials in the multi-media language lab. In other words, students read an abundance of relevant material about a topic and then wrote about it. The web materials in the Web Quest offered the kind of language input that Chen (2011) described as possessing "linguistic complexity, quality, quantity, variety, genuineness, and relevance” when he commented on the capability of computer technology in providing input to language learners. The traditional critical reading instruction was reading comprehension passages in the book of Move Ahead Plus for the first year experimental secondary stage students and teacher-directed oral discussion held in a regular classroom.

Improvement in students' critical reading comprehension ability could be due to the knowledge of vocabulary and content that the students gained from the Web Quest lessons. The students stated clearly in their sessions the usefulness of the Web Quest sessions in providing them opportunities to learn new vocabulary and content knowledge when they were exposed to a lot of reading materials. This is supported by the view of Nation (2002, p. 267) in that “reading has long been seen as a major source of vocabulary growth”. Moreover, both L1 and ESL/EFL research studies have provided evidence showing the possibility of incidental vocabulary learning through repeated exposure (Pigada \& Schmitt, 2006). Besides, practice is necessary for improvement in reading. According to Ranandya and Jacobs (2002, p. 300), “people learn to read, and to read better, by reading”. The more chance of reading practice the students have, the more chance of reading improvement they are likely to get.

\section{The Effect of Web Quest on Students' Writing}

The Web Quest can be more effective than the traditional process writing instruction (see Table 3) for many reasons:

(1) The writing input in the traditional process writing instruction was printed material and teacher-directed 
oral discussions held in a regular classroom. The process writing input in Web Quest was the printed materials in the book of Move Ahead Plus for the first year experimental secondary stage students and the web materials presented on given websites. Students surf the web materials, critically read them and then wrote about them using the reading to writing approach. Critical reading was used as an outside source. Research on second language reading and writing connections also suggested that learners may improve their writing ability if they are exposed to reading texts in a process of communication (Leki, 1992; Abu Rass, 2001; Elley, 1991; Ghawi, 1996). Thus, students in the WQCRWP probably outperformed their counterparts in the traditional process writing instruction because the former spent a substantial amount of time skimming, scanning and deciding relevant web materials for the purpose of commenting their ideas in their writing.

(2) Web Quest can be effective for improving students' writing skill and this was clear by their actual writing improvement shown by the writing test. Students also perceived that Web Quest was effective in relation to their reading skill. This finding is not surprising in that the reading to writing approach was employed in the Web Quest. Exposure to abundant and varied resources in English was one of the advantages most often mentioned by the students. Students felt that accessing and surfing the web materials relevant to the writing topics benefited them a great deal for their actual writing process. Accessing and surfing web materials primarily involved the act of reading, which may lead to students' perception that they improved their reading skill in addition to their writing skill.

\section{Limitations of the Study}

\section{This Study Was Limited to the Following}

First year experimental secondary school students.

Using some EFL process writing skills: length, purpose, genre, content, organization, vocabulary choice, and language mechanics.

Using some critical reading skills: identifying the main idea, recognizing the author's purpose, identifying the author's bias, making inferences properly, recognizing relation between reasons and effects, analyzing denotations and connotations of words, making predictions properly, making comparison and contrast, recognizing the author's tone, drawing logical conclusions, evaluating arguments, identifying fact and opinion, making generalizations, and identifying hidden assumptions and making good summary.

\section{Conclusion}

Web Quest is one of the most up-to-date computer technologies which teachers use with their students. This study provides data showing that students' critical reading and writing can be improved with Web Quest. It is possible that EFL instructors can make use of Web Quest as a current technology to help their students develop their critical reading and writing.

\section{References}

Abdel-Razek, T. (2006). The effectiveness of the genre-based approach in developing the writing skills for EFL first year secondary school students (M.A. Thesis, Faculty of Education, Helwan University).

Abu Rass, R. (2001). Integrating reading and writing for effective language teaching. Forum, 39(1), 30-43.

Chen, Ch. (2011). Using Web Quests to facilitate task-based English reading instruction for graduate students. Chinese Journal of Applied Linguistics (Quarterly), 34(2), 32.

Dodge, B. (1995). Web Quests: For Internet-based learning. Distance Education, 1, 10-13. 
Ebada, M. B. (2002). The effectiveness of using Socratic method and the debate technique on promoting some critical thinking skills through teaching the English language story for the secondary stage students (M.A. Thesis, Faculty of Education, Helwan University).

Elley, W. (1991). Acquiring literacy in a second language. The effect of book-based programs. Portsmouth, NH: Heineeman.

Ghawi, M. (1996). The adjunct model: A model: A case study on a pre-course. (Doctoral Dissertation, Tucsuni University of Arizona).

Hyland, K. (2002b). Teaching and researching writing. Edinburgh Gate, England: Pearson Education Limited.

Helal, E. (2005). A proposed self-access program for developing English language writing skills for first year secondary school students (M.A. Thesis, Women's College for Arts, Ain Shams University).

Kamal, R. (2010). The effectiveness of a suggestive strategy for developing English language critical reading skills among experimental primary school pupils (M.A. Thesis, Faculty of Education, BenhaUniversity).

Key, J. $\quad$ P. $\quad$ (1997). $\quad$ Qualitative $\quad$ research. Retrieved July 24, 2007, from http://www.okstate.edu/ag/agedcm4h/academic/aged5980a/5980/newpage21.htm

Kocoglua, Z. (2010). Web Quests in EFL reading/writing classroom. Procedia Social and Behavioral Sciences, 2, 3524-3527.

Leki, I. (1992). Understanding ESL writers: A guide for teachers. Portsmouth, NH: Heinemann.

March, T. (1998). Web Quests for learning: Why Web Quests? An introduction. Retrieved June 2008, from http.//wwwrozline.com//intro/html

Nation. (2002). Best practice in vocabulary teaching and Learning. In J. C. Richards \& W. A. Renandya, (Eds.), Methodology in language teaching: An anthology of current practice (pp. 254-267). New York: CUP.

Philips, A. N., \& Sotiriou, P. (1992). Steps to reading proficiency. Belmont: Wadsworth Publishing Company.

Pigada, M., \& Schmitt, N. (2006). Vocabulary acquisition from extensive reading: A case study. Reading in a foreign language [Online]. Retrieved August 3, 2006, from: http://nflrc.hawaii.edu/rfl/April2006/pigada/pigada.html

Puthikanon, N. (2009). Examining critical thinking and language use through the use of Web Quests in an EFL reading class. (Doctor's Thesis, faculty of the University Graduate School, Indiana University).

Renandya, W. A., \& Jacobs, G. M. (2002). Extensive reading: Why aren’t we all doing it? In Richards, J. C. and Renandya, W. A. (Eds.), Methodology in language teaching: An Anthology of current practice (pp. 295-302). New York: CUP. 